\title{
TTR
}

Traduction, terminologie, re?daction

\section{Artistic Translation in the Interliterary Process}

Dionýz Ďurišin

Volume 4, numéro 1, 1st semester 1991

Languages and Cultures in Translation Theories

URI : https://id.erudit.org/iderudit/037085ar

DOI : https://doi.org/10.7202/037085ar

Aller au sommaire du numéro

Éditeur(s)

Association canadienne de traductologie

ISSN

0835-8443 (imprimé)

1708-2188 (numérique)

Découvrir la revue

Citer cet article

Ďurišin, D. (1991). Artistic Translation in the Interliterary Process. TTR, 4(1),

113-127. https://doi.org/10.7202/037085ar

Tous droits réservés @ TTR: traduction, terminologie, rédaction — Les auteurs, 1991

Ce document est protégé par la loi sur le droit d'auteur. L’utilisation des services d'Érudit (y compris la reproduction) est assujettie à sa politique d'utilisation que vous pouvez consulter en ligne.

https://apropos.erudit.org/fr/usagers/politique-dutilisation/

Cet article est diffusé et préservé par Érudit.

Érudit est un consortium interuniversitaire sans but lucratif composé de l’Université de Montréal, l’Université Laval et l'Université du Québec à

Montréal. Il a pour mission la promotion et la valorisation de la recherche.

https://www.erudit.org/fr/ 


\section{Artistic Translation in the Interliterary Process}

\section{Dionýz Ďurišin}

The problem of what we term artistic translation represents a specific domain of investigation in the interliterary process. This is primarily due to the fact that artistic translation is one of the most striking expressions of interliterary interaction. Its ontological essence resides in its being a product of interliterary communication. ${ }^{1}$ But being simultaneously a form of reception, it also conditions and determines the latter. Thus, it is not by chance that in our systematics we have set it apart from standard consequences of a perception/filiation, allusion, etc., as a phenomenon which points more directly than any of the remaining forms of contact relationships to the orientation of the interliterary process and concretizes more directly the content of interliterariness. Consequently, we have devoted concentrated attention to it also in the first stage of a team investigation of specific interliterary associations, and this not solely in our introductory instructive project, ${ }^{2}$ but also in three special studies designed to investigate the specific character of

1. Miko, F., "Vergleichsstilistik und Ubersetzung / Comparative Stylistics and Translation," in O medziliterárnych vzt'ahoch (Bratislava, Slovenské pedagogické nakladatel'stvo, 1968, pp. 237-239).

2. Durišin, D. "Osobitné medziliterárne spoločenstvá. /Specific Interliterary Associations," in Dionýz Durišin et al., Osobitné medziliterárne spoločenstvá 1. (Bratislava, VEDA SAV, 1987, pp. 10-25). 
artistic translation precisely within these literary-historical structures. $^{3}$ On that occasion already we tentatively formulated the mediative external and internal functions of artistic translation, a supremacy of its creative, and a reduction of its transpositive function; more or less hypothetically we set up the category of a translative dioecism and the well-known category of "second-hand translation," or translation of translation. The latter category in particular, has received adequate elucidation, concrete justification and functionality, only in the system of specific interliterary associations. It may be of interest to observe that these stimuli, strikingly evident in current practice, have not been utilized in concrete literary-historical considerations, as shown, for instance by research on the category of di-, or poly-oecious translation.

\section{a. Translation Di-, Poly-Oecism}

Translation di-, and poly-oecisms occur in practice in every case of mono-, bi- or poly-lingualism, and to this is related bi- or polyliterariness. It was applied in a very modest measure in a team research project on the relevant individual interliterary associations. And at the same time, it exists objectively in the Slavonic interliterary association, in the community of Yugoslav literatures, not solely in the specific interliterary association of Eastern Slavs, but also in those of the Soviet Union. Translation bi-, poly-oecism is undoubtedly functional among literatures of the British Isles, thanks among other factors, to the mediating function of English among Irish, Welsh and Scotch literatures. Its potential and concrete presence may be spoken of, e.g. in the Swiss complex, and this in relation to French, German, and Italian literatures, then in Anglophone, Francophone literatures, in literatures making use of Spanish, Portuguese, etc. Objective conditions exist here for a translation of some - though by no means of all - works to function, often with equivalent meaning in two or more national

3. Rahoysha, V. "Východoslovanské medziliteráme spolođenstvo a umelecký preklad. /East-Slavonic Interliterary Associations and Artistic Translation," ibid. (pp. 43-59). Dionýz Durišin, "Funkcia prekladu v osobitnom medziliterámom spolotenstve. /Function of Translation in a Specific Interliterary Association," ibid. (pp. 60-73). "Fajbula Salomov and Komilzhon Zhurayev: Bilinguismus a preklad $\mathbf{v}$ medziliterárnom spolocenstve. Bilingualism and Translation in the Interliterary Association," ibid. (pp. 244-257). 
literary systems and thus to achieve the status of di-, or polyoecism.

Nevertheless, translation dioecism ${ }^{4}$ is not a current phenomenon, and finds the best prospects for its existence under conditions of specific interliterary associations thanks to refined, even subtle, direct forms of interaction and interliterary communication. Research into this phenomenon offers a rewarding field of investigation, revealing precisely those forms of interliterary bonds which escape attention when the research follows other literary-historical aspects. Thus, for instance, translation dioecism may lead to a certain form of genre modification of the translated work, and this mainly in its concretization by the receiver. For di-, or polyoecism means in fact a functioning in a different mode in different literary systems. This function in a different mode may in some cases refer also to a genre identity of the translation, or may bring about a certain shift in the explanation of the original's genre identity. Numerous examples in the interliterary process lend support to this fact, yet, in view of the susceptible nature of the entire issue, there are frequent and unavoidable discussions around the concretization of such shifts and changes in the genre of reception of the translated original.

For example the existing consciousness of a kinship between Czech and Slovak literature resulted not only in that Slovak translation efforts often took direct contact with analogous efforts in Czech literature, but that they mutually supplemented one another in a creative manner, making use of the complementary function. But there were cases when a Slovak translator, - not that he would have been unaware of the existing literary solidarity of Czechs and Slovaks stemming from the existence of a specific interliterary association of the Slovak and Czech literatures, but rather reckoning with it, creatively built on it in his translation strategy. For example, from Gogol"s "Evenings on a Farm near Dikanka," Nezabudov translated into Slovak precisely the three short stories that until then had no Czech variant: "Lost Letter,"

4. Translation dioecism testifies to the existence of translation in two cognate, yet differing literary conventions. Its functioning in two or more literary systems is possible in fact, thanks solely to an "identity" of the literary work - as analyzed by F. Miko in his study "Preklad a totožnost" diela. /Translation and Identity of a Work," Romboid, 20, no. 11 (1985), pp. 32-37. 
"Bewitched Town" and "Midsummer Night." Undoubtedly, Nezabudov respected the setting up of the short story as a literary genre in Slovak literature and thus applied the genre aspect in this translation selection. However, he simultaneously reckoned with the aspect of a temporary dioecism of the translation of these stories which had all the prospects of functioning not only in Slovak literature, but in a different mode, also in Czech literature, until of course they were translated into Czech. On the other hand, translation dioecism was quite concretely realized the other way round in that the existing Czech translations acted as complementaries in Slovak period literature by temporarily filling the gap caused by the absence of a Slovak translation of the other stories in Gogol"s Evenings. This is a subtle, literary-historically concrete case of the so-called mutual translation dioecism - showing an implementation of complementarity in the domain of translation.

Such a mutual, or one-sided dioecism of artistic translation is applied in relations between literatures in which linguistic circumstances permit reception of a third-language translation. Many cases exist in numerous types of interliterary associations, but also outside of them, when choice of translations and application of certain translation procedures and solutions are conditioned by aspects of genre and style. This very fact causes the translation to lead to a certain modification of the genre and style form of the original - despite the existing identity of translation with the original, the process of interliterary communication may give rise to a polystructural interpretation of the original in the translation. Such a modifiableness of translating conceptions is a historical phenomenon, and it may be inferred from the concept of literary convention as one of the systems categories of historical poetics.

\section{b. Style-Genre Aspects of Artistic Translation}

Genre is not a rigid, temporally immutable quality. It is governed by various determinants, primarily by categories of social consciousness integrated in the literary process. Hence, we must realize that translation does not involve merely a straight-lined transmission of an original's genre constants, but likewise their modification, and this in dependence on the manner and intensity of genre determinants in the receiving literature. From this we infer that the genre aspect is subject to the action and changes of a hierarchically higher literary system which is literary style, or style formation. Literary style comprises a period genological usage as a 
concrete genre configuration in a given period, further, relationships between literature and reality embodied in the rules of literary development, the methodological literary-scientific system, hence, a period literary-scientific consciousness. Implicitly, it is also the bearer of elements of a specific developmental process of national literature, which is simultaneously hierarchically determined. In view of the direct mutual bond between genre and style aspects, terminologically we use the term "style-genre" aspect, being conscious not only of the integrative trends of these indicators of translatability, but also of their divergence.

These categories of historical poetics characteristically overlap and mutually determine in every single case and in every developmental period. While rules of the literary genre are the most direct criterion of translation procedures, because every literary work is subject to a certain genre classification and because a literary genre screens out immediately and concretely components of expression, thereby determining the comparative confrontation of the translating transformation, literary style fulfils the function of a more general indicator. The style-genre aspect thus becomes projected into various planes of the interliterary process and embodies all the literary-historical units beginning with the work, through interliterary associations, and ending in world literature.

From our literary history we know that P.O. Hviezdoslav's translations had, ultimately, been motivated principally by style and genre aspects, which became manifest in his very choice of predominantly romantic writers in world literature at the time of a full development of Slovak literary realism. A significant role in this choice was also played by the specific ways of development of Slovak literature which, for objective reasons, did not realize all the forms of European romanticism. Hviezdoslav's selection from German, Hungarian, Polish or Russian romantic writings may, in these relations, be understood also as an endeavour subsequently to make up for a lack of this developmental layer in Slovak literature with his translations. Also the romanticizing trends in Hviezdoslav's original writings correspond to this design, ${ }^{5}$ as well as his

5. Štanislav Šmatlák (Dejiny slovenskej literatúry. /History of Slovak Literature - III, Bratislava, 1965, p. 710) states: "Hviezdoslav then embodies within him both the basic literary trends of his epoch: 'realist' and 'romantic', and out of the two, he builds up a specific artistic world of his work." Cf. Jozef Felix's reflection 
translating technique of e.g. Pushkin's Gypsies. An analysis of Hviezdoslav's translation of this work reveals e.g. that while Pushkin, portraying the Gypsies' life environment, makes use of "expressions fee of emotional charge, neutral, Hviezdoslav underlines a different aspect, precisely that wildness - exuberance, which he explains in his own manner. He introduces expressive words into his descriptions, but also into the speech of the characters, using even a certain verbal feat of strength..."

The genre aspect came out also in a preliminary analysis of the translation of the Song about the Merchant Kalashnikov in connection with the mode of translating artistically symbolic lexical units, or elements of the metrical structure of the verse. In contrast to an earlier translation of this work and its newer Slovak translation, in both of which an obscured meter predominated, Hviezdoslav replaced tonic verse with a period topical syllabic meter. ${ }^{7}$

An absolutization of the deciphering analytical aspects in the translation process is characteristic of the extreme conception in this work and essentially tends towards the so-called slavish translation. In the interliterary process it evokes associations with diverse forms of "dependence" and "influence." In interliterary relationships this tendency is manifest principally in those developmental areas that are characterized by various forms of developmental "defensive measures" on the part of the receiving literature, even though genological aspects condition neither translation procedures, nor yet translation selection. This is an extreme position expressing a trend rather than reality.

The prevailing stress on the deciphering aspect at the expense of translating creativity results in a translation empiricism, and the methodology of translation leads e.g. to statements that the

over the 3rd vol. of the History of Slovak Literature. /Slovenska literatúra (1966, no. 5, pp. 513-521).

6. Tuř̌ny, V. "K poetike Hviezdoslavových prekladov. IOn the Poetics of Hviezdoslav's Translations." Slovenská literatúra (1960, no. 4, p. 424).

7. Ďurisin, D., "O literárnych vzt'ahoch. /On Literary Relationships" (Bratislava, VEDA, VSAV, 1976, p. 152). 
translator works primarily with elements at lower linguistic planes of the text. Yet the inner subordination of explicitly linguistic planes of the text to those of artistic segmentation is an inherent requirement of a literary translation.

It may be said in general that work with exclusively linguistic elements of a text comes out strikingly to the forefront in writings which, for one reason or another, negate a certain mode of stabilized subordination, correlatedness of various elements of the literary text. Such are, for instance, translations of some surrealistic verses which not only fail to respect the traditional bonds among verses, but refute also the stable bonds of meaningful elements.

Let us take note of the way the Slovak translator Vladimir Reisel proceeds in translating Breton's poem "Le Buvard de cendre $^{18}$ (Blotter of Ashes):

Le buvard de cendre

Les oiseaux s'ennuieront

Si j'avais oublié quelque chose

Sonnez la clochade ces sorties d'école dans la mer

$\mathrm{Ce}$ que nous appellerons la bourrache pensive

On commence par donner la solution du concours

A savoir combien de larmes peuvent tenir dans une main de femme.

$1^{\circ}$ aussi petite que possible

$2^{\circ}$ dans une main moyenne

Tandis que je froisse ce journal étoilé

Et que les chairs éternelles entrées une fois pour toutes

en possession du sommet des montagnes

J'habite sauvagement une petit maison du Vaucluse

Cour lettre cachet

Piják z popola ${ }^{9}$

Vtáci sa budú núdit'

8. Breton, A. Clair de terre (1966), p. 64.

9. Breton, A. MuŽ a Žena cisto bieli. IMan and Woman All White (Bratislava, 1964), p. 15. Transl. by Vladimír Reisel. 
Keby som tak bol cosi zabudol

Zazvonte na odchody zo skoly do mora

A budeme to volat' zamysleným borákom

Zacínajú vyhlasovat ${ }^{\circ}$ výsledky skúšok

To jest kol ko sl'z unesie ženská ruka

Po prvé: najmenšia

Po druhé: ruka stredne vel'ká

Zatial' to krčim hviezdne noviny

A vexných tiel sa navždy zmochuje horský vrchol

Divoko bývam $v$ malom domci vo Vaucluse

Srdce král'ovský zatykač

An English rendering might run as follows:

Blotter of Ashes

Birds would be bored

If I had forgotten something

Ring the bell for leaving the school into the sea

And we'll call it a pensive borage

They start giving the results of the contest

To wit how many tears will hold in a woman's hand

1 st in the smallest one

2nd in an average-sized

While I crumple this starred diary

And the eternal bodies entered once for all in possession of mountain peaks

I live wildly in a little house of Vaucluse

The heart a king's warrant

Under certain circumstances the Slovak version of the poem might be designated as a translation "between the lines" (Russian "podstrochnik"), or in a certain sense, as literal or lexical translation. The translator thoroughly respects the meaning of the various words and phrases, and insofar as Slovak permits, he strives even to preserve the grammatical means of the original (Le buvard de cendre - Pijak z popola, les oiseaux s'ennuieront vtáci sa budú núdit"; d'école dans la mer - zo školy do mora, etc.). We might consider as "literal" also his solution where "literalness" is outwardly disrupted by different phraseological possibilities of the two language systems: Sonnez la cloche zvoȟte; A savoir - to jest; une fois pour toutes - navždy, and others. 
This mode of translator's relation to the original and the resulting translating concretization is essentially predominant, and derives from a respect for the original's poetics and its style determinancy. This translation "literalness" was programmed and within the framework of the surrealist literary style, it systemically encompassed a negation of traditional forms and meanings. It is in fact the only way to transform e.g. elements of psychic automatism, associations of subconscious or hypnotic states which determine surrealism as a literary movement and its conspicuous innovative traits in relation to preceding traditions. A translating conception that failed to respect these traits of a poem by bringing in any elements of binding, would come into conflict precisely with the style-genre character of the original.

However, a more thorough analysis of the translation will reveal certain procedures of an individualized translating concretization. This is most saliently apparent, e.g. in not respecting the manner of the graphic rendering of the French $1^{\circ}-2^{\circ}$, premièrement, deuxièmement - firstly, secondly/ with the aid of numerals. The numeric form, reckoning in the original also with a visual effect, is certainly more symptomatic of surrealistic procedures than its transcribed verbal expression. While Breton, in conformity with the style programme of surrealist poetry, formalized the meaningful parallelism in a maximum measure through the use of numerals, the Slovak version adhered but partially to this trait of the original. The nontraditional procedure of the original is not completely lost in the translation, yet functionally we must see in it a compromise solution: the translator sacrificed something from the "nontraditionalism," yet simultaneously conformed in some degree to convention. Similarly, the translation of the French expression "Aussi petite que possible" by the Slovak "najmensia" (the smallest one) does indeed preserve veracity of meaning, yet simultaneously is a simplification and a somewhat more direct structural equivalent. Occasionally, Reisel tends towards a meaningful concretization of statement, e.g. through a stylistic emphasis on the demonstrative pronoun "to" (that), introducing into the text the coordinative conjunction " $\mathrm{a}$ " (and) in the sentence "A budeme to volat zamysleným burákom" (And we'll call it a pensive borage) - in comparison with the original "ce que nous appellerons..." A tendency to concretize statements is apparent also in an enrichment of the text with the adverb "tak" (somehow). "Keby som bol tak cosi zabudol" ("Si j'avais oublié quelque chose". If I had "somehow" forgotten something). These interventions introducing elements of concrete- 
ness into the translation, contribute to a strengthening of the continuity, the coherence of the text. While rigorously adhering to the poetics of the original, we may therefore consider them as nonsystematic on the one hand, yet on the other, precisely these and similar interventions constitute a regular indication of an individualized concretization of the original. On the literary-historical plane they are conditioned by the period assignment of the translation within the context of the receiving literature, by the receiving convention and the translator's subjective interpretation of the poetics of the original. In a creative translating process such factors are natural, for they are the bearers of the translation's functionality in the interliterary process. If we grasp this fact, we shall understand "literalness" also in these extreme cases as being markedly relative and we shall not see in it the translator's or the critic's incompetence to decipher the distinctive poetics of a poem and the manner of its artistic structuring.

In essence, this involves an ability to discover the forms of modifying linguistic elements of the text on the interliterary and literary-artistic planes, between which a significant role is played by the style-genre aspect. This is not affected in any way by the fact that artistic effect in surrealist poetry is achieved precisely through the absence of elements of the traditional structuring of the poetic text. True, surrealist devices are perceived against the background of certain usages as nonexisting artistic procedures, yet from the semiotic point of view, precisely this absence is systemic. Although it may appear paradoxical on the outside, absence of an artistic materialized means is in fact a functional procedure characterizing surrealist poetry per se and making it perceptible from the aspect of certain practices.

Genre is an immediate classificatory measure of literary works also in the coding process, determining and defining them primarily and directly. A literary-historical explication of a work assumes, in the first place, a determination of its genre assignment or classification. This may be vividly demonstrated on examples of works from remote developmental periods where the style-genre factor of the original and of the translation are considerably divergent. In extreme cases, there may occur a diametrically opposite classification of style-genre realia, and even a total levelling out of the genre appurtenance of the original. Suitable examples are provided by translations of Biblical texts, and this particularly of the temporally remote texts of the Old Testament, but of the New Testament, too. The intent to achieve the most thorough, even 
slavish fidelity, reinforced also by the conviction that there was question of God's inviolable Word, led translation practice, as also the explanation of individual texts, to a complete levelling off of the species or genre appurtenance. The various texts were understood on the plane of a current linguistic announcement without account being taken of their period genre assignment. More recent translation theories expound these texts against their genre background as allegory, heroic poem, fable, parable, legend, myth, ritual prescription etc., and strive exactly to define those of their signs that are characteristic of the period genre usage.

The style-genre aspect comes out strikingly as a determinant of the translation process, e.g. also in connection with the Slovak translation of Gogol"s Tales of Petrograd, from $1950 .^{10}$ This is noticeable in the different exposition of Gogol"s model by the translating team, on the one hand, and the critic of the translation, V. Kochol, on the other." ${ }^{11}$ The translating team interpreted some of Gogol"s novels as works in which the various artistic procedures were conditioned by a concrete style-genre assignment, or classification. We might characterize it as a specific developmental tension between romantic and realistic procedures. Whence the interpretation e.g. of Gogol"s The Nose as a parody on romantic automated fantasticalness with a double projection of the personage and identification of man with, e.g. his reflection in the mirror, his shadow, or in a concrete case with a part of human anatomy - the nose. An analogous translator exposition had also been that of Kepen and other stories. In the spirit of this stylegenre exposition, the translating team set off, besides other points, also the parody of the original, but paid less attention to the critico-realistic layer of his elements in plot construction. The initial determinant of the genre specificity was primarily the translators' literary-scientific consciousness.

Viktor Kochol started from a different theoretical model and therefore, in his critical analysis he laid stress above all on the critical-realist layers of the Petrograd novels. His classification of the style of the tales was more explicit and he also understood

10. Gogol', N.V., Petrohradské novely. /Petrograd Novels (Bratislava, 1950).

11. "Skreslený Gogol’. Distorted Gogol," Slovenské pohl'ady, 68, no. 7-8 (1952), pp. 579-598. 
more explicitly their genre determination. In this way, the Petrograd novels were interpreted primarily as socio-satirical novels and their parody in relation to the romantic fantasy appeared as an irrelevant element. Such an interpretation was conditioned in a decisive manner by the style-genre literary consciousness in the 50 s, which provides support also to the view that one of the expression-determinants of genre-specificity is, besides literary usage, also the methodological literary system.

Kochol, in the spirit of his interpretation of Gogol"s Petrograd novels with a determining socio-satirical layer, criticizes the translating team's excessive fondness for foreign words, where the original gave priority to words of home origin (e.g. "pestrota lits" - "kaleidoscope of faces" instead of "colourfulness of faces"; "ya dlya shtuki poshol $v$ department" - "for my own plaisir I went up to the office" - instead of "Through caprice, I went up to the office"; "zdelat otnosheniye" — "v siyu zhe minutu" - "stante pede"; and so on), further, in cases where a foreign word in the translation stylistically intensifies the expression in the original ("pelerina" - "balustrada"; "tsyryulnik - "barbier"; "arendy" "fundus"). Alongside a spate of foreign words, the translators used numerous jargons, cant, vulgarisms and lexical expressions which generally strengthen or shift the genre characteristic of novels, occasionally modify the structure of personages. This was related to the translator's conviction that Gogol"s novels are primarily parodies of procedures employed currently in automated romantic aesthetics. On the other hand, it should be observed that Kochol failed fully to appreciate this layer of the Petrograd novels in the spirit of the contemporary negative attitude to a comparative investigation of literature. And thus we are faced here with diametrically opposite style-genre interpretations of Gogol"s tales, conditioned both by period aesthetic usage and a divergent interpretation of the genetic-historical value of the work. At the moment it is irrelevant which of the above attitudes corresponds to the so-called objective interpretation of Gogol"s novels, although, in our view, there is question of extreme standpoints in either case, for the genetichistorical value of Gogol"s novels encompasses primarily the sociosatirical aspect - yet, simultaneously also the aspect of a parody reaction to romantic aesthetics. Affinities of the Petrograd novels with the contemporary European literary movement cannot be ignored. On the other hand, the above Slovak translation provides a convincing proof that translating strategies are conditioned by the translator's and eventually the interpreter's style and genre subcon- 
sciousness and documents even a conspicuous genre differentiation from the original.

Examples of genre modification in translations abound, and there would be no point in summarizing them. But let us stop at a further category, characteristic particularly of specific interliterary associations, viz, at a category inconsistently investigated, although fairly frequent in current practice, "second-hand translation," or translation of translation.

\section{c. Translation of Translation}

This phenomenon does not occur solely under conditions of specific interliterary associations, but appears wherever the required bilingualism is lacking and the translator is consequently dependent on a mediating language. However, under conditions of specific interliterary associations, translation of translation is a very frequent phenomenon and this, in particular, in relations between the more and the less differentiated literatures, in cases when a certain literature performs a mediatory function in relation to another literature. This often involves not merely a linguistic mediation, but also one of literary procedures and artistic solutions. Again, examples are plentiful. Suffice it to recall the mediating linguistic function of Russian in the translation of most literatures in the multi-nationality Soviet literature. This often involves also the mediation of literary artistic forms spoken of above, and of procedures in those cases where the translator takes over not only the language, but likewise a Russian substitution of literary-artistic solutions of the original. In such cases we deal with the so-called Russian, or foreign filtre of the mediated work, with its modification, adequate to the poetics of Russian or other literature, etc. It might be observed that in those cases where artistic procedures are not taken over, the foreign translation in point of fact performs only the function of "podstrochnik" - a word-for-word, lexical translation. The only difference is that with current "podstrochnik," there is the question of the translating language, whereas in the case of translation of translation, the function of "podstrochnik" is performed by a foreign language system. As a rule, however, this language mediation also carries with it - often unconsciously from the translator's point of view - certain artistic procedures. This represents a very interesting and delicate area of interliterary relationships, that helps to enrich our knowledge of the interliterary 
process and interliterariness with numerous laws of interliterary communication.

The function of "second hand translation," i.e., translation of translation is a versatile one and does not mean only the linguistic or creative aid of an erudite foreign translator. We meet with such a motivation of "second hand" translation e.g. in translations of Russian literature during the course of the 19th century, but especially in the 80 s, when Andrej Trúchly Sytniansky was editorin-chief of the Slovak literary magazine Orol. ${ }^{12}$ A.T. Sytniansky took as his aim in his editorial work to extricate Slovak literary life from its regional seclusion by making accessible to the Slovak reader significant works of international writings. The concern during this period was also to promote the development of the short story. A direct testimony to this programme are the numerous translations from B.N. Nezabudov's pen, but also Sytniansky's own translations of such authors as J.C. Andersen, B. Björnson, L.N. Tolstoy, N.V. Gogol', O.S. Turegenev, M. Czajkowski, and others. The weight which Sytniansky ascribed to such editorial formative activity became reflected in his own translation work which was less concerned with the inner relation to artistic procedures in the works being translated, than with an external attitude towards them. Hence, it was nothing unusual for Sytniansky to translate "from second hand," from existing magazines, as is borne out by his translation of Gogol"s Viy, Turgenev's Sportsman's Sketches, etc. The aspect primarily enforced here was one of choice, and less attention was devoted to translation conception.

Translation of translation exists in many literatures belonging to the language area spoken of above and there is no need again and again to emphasize its literary-historical and theoretical characteristics. Nevertheless, we choose to recall it under conditions of the former and existing colonial and neocolonial relationships where the language and literature of the metropolis played analogous mediating functions with a certain neglect of the measure of specificity. An investigation of specific interliterary associations may not bypass these specificities, just as we may not bypass them

12. Conceming "second-hand" translations from Russian literature, cf. Anton Popovic, Ruská literatúra na Slovenská v rokoch 1863 1875. IRussian Literature in Slovakia in the years 1863-1875 (Bratislava, SAV, 1961, pp. 108-118). 
in our effort at reconstructing the developmental process of world literature in its various historical periods.

In this connection it should be observed that the concrete literary-historical studies in the first volume of Specific Interliterary Associations did not sufficiently utilize stimuli orienting research and investigation of the inner and outer mediating function and this irrespective of whether it was performed by the original production of a given literature, or through artistic translation, where often a translation of translation is involved. And yet, the mediating function realized either by the original or the translation is essential to any form whatever of interliterariness. Moreover, it is present as a certain starting point for all the forms of interliterary communication mentioned or dealt with above. 